\title{
The productivity potential of black cherry varieties when growing in the arid zone
}

\author{
E.N. Ivanenko, and T.V. Menshutina* \\ FSBSI "Caspian Agrarian Federal Scientific Center of the Russian Academy of Sciences", 416251 \\ Astrakhan, Russia
}

\begin{abstract}
For the first time in the conditions of the arid climate of the Astrakhan region, the primary study of black cherry varieties of different maturation periods was carried out. The experience started in 2003 in the experimental fruit garden of the Caspian Agrarian Federal Scientific Center. The objective of the research is to assess the productivity potential of black cherry varieties based on a long-term study of their yield and to determine the most adapted one to the stress factors of the winter period. Aprelka, Salgirnaya, Negrityanka, Galochka, Mlievskaya Chernaya and Krasavitsa varieties were planted according to the scheme 6 × 4 m (416 tree/ha), rootstock - the seedlings of cherry-Rastunya. It was found that the productivity of black cherries depended on the weather conditions of the winter-spring period. In conditions of cold winters, as well as with significant temperature changes in winter and return frosts, the yield significantly decreased. The most productive varieties were Aprelka (control) and Krasavitsa, which most fully realized the potential of productivity during the entire period of operation of plantings. The average productivity over the last 5 years of commercial fruiting was 13.2-13.9 $\mathrm{kg} /$ tree or 5.5-5.8 t/ha. Negrityanka, Salgirnaya and Mleevskaya Chernaya varieties also had sufficiently high productivity (10.2-11.7 kg/tree) or 4.24.9 t/ha). The Galochka variety was characterized by high resistance of generative buds to return frosts. The obtained data indicate the possibility of successful cultivation of black cherries in the specific climatic conditions of the Astrakhan region using varieties with increased winter hardiness.
\end{abstract}

\section{Introduction}

Black cherries are very popular due to the early ripening period, high transportability, attractive presentation and good taste of the fruit. The high content of sugars, ascorbic acid, vitamins, R-active substances, carbohydrates and organic acids in the fruit determine the interest in this crop, both in industrial and household gardening. These advantages and the high selling price, in turn, make black cherries economically profitable products $[1,2]$.

Today, Turkey (438 thousand tons), the United States (284 thousand tons) and Iran (180 thousand tons) are the leaders in the production of black cherries in the world [3]. The Russian market remains unsaturated, as almost $90 \%$ of all black cherries are grown in the

\footnotetext{
*Corresponding author: Pniiaz@mail.ru
} 
private sector. Black cherries come to the domestic market from the former Soviet republics (Uzbekistan, Azerbaijan, Ukraine), Europe (Italy, Spain, Portugal, Greece, Poland, Germany, the Netherlands), Western Asia (Syria, Turkey, Iran) [4,5].

Black cherries are grown mainly in the southern regions. Nevertheless, even in the southern zone of fruit growing in Russia, the creation of annually fruitful, highly productive industrial gardens of this crop is largely limited by the genetically pronounced weak winter hardiness. The correct selection of varieties that combine high potential biological productivity with sufficient winter hardiness is necessary [6-8].

Winter hardiness - the ability of a fruit plant to to endure a complex of unfavorable winter conditions, determines the area of effective use of the variety, its productivity, production and economic value $[9,10]$.

Under generally favorable soil and climatic conditions, the limiting factor of widespread black cherry cultivation in the arid climate of the Astrakhan region is the weak resistance of flower buds to winter stress factors. In the conditions of the region, the most relevant are the resistance of generative buds to temperature changes in winter, which are observed almost annually in the last decade and have the character of sudden impacts (stresses), resistance to return frosts in spring. Sometimes in the territory of the region in the middle of winter, disastrous negative temperatures are noted. Taking into account the climatic features of the Astrakhan region, a more detailed approach to the selection of black cherry varieties for its cultivation, an assessment of the duration of the productive period and the durability of the plantings is required.

In the Lower Volga region (Kalmykia, Volgograd, Astrakhan and Saratov regions), the issue of black cherry sorting has still not been resolved more or less satisfactorily. Currently, only 2 varieties of black cherries are allowed for use: Daybera Chernaya (originator - the North Caucasus Federal Scientific Center for Horticulture, Viticulture, and Winemaking) and Rannaya rozovaya (originator - the Rossoshanskaya Zonal Experimental Station of Horticulture), which have never been grown in the Astrakhan region. There is no data on how they realize their production and adaptation potentials in the specific climatic conditions of the arid zone.

Conducting a variety study to identify the most highly productive varieties that are most adapted to specific soil and climatic conditions is relevant. Currently, the study and selection of adaptive black cherry assortment is carried out not only in the regions of the Lower, but also in the Middle Volga region [1,11]. The objective of our research is to assess the productivity potential of black cherry varieties based on a long-term study of their yield and to determine the most adapted one to the stress factors of the winter period of arid climate.

\section{Material and methods of research}

The objects of research were 6 varieties (Aprelka, Salgirnaya, Negrityanka, Galochka, Mlievskaya Chernaya and Krasavitsa) of different ripening, chosen in the collection the Volgograd experimental station of VIR for primary cultivar in the experimental orchard of the Caspian Federal Agrarian Scientific Center in Chernoyarsky district of the Astrakhan region. Varieties implanted on seedlings of cherry-rastunya were planted in 2003 on 5 trees each in three-fold repetition with a placement scheme of $6 \times 4 \mathrm{~m}$, the arrangement of variants is systematic. As a control, the Aprelka variety was used, which for a long time was in zoning in the Lower Volga region. The assessment of winter hardiness was carried out by the field method. Every year, during the separation of buds accountings of generative buds freezing were conducted; after flowering - accountings of freezing of bark, peaks of annual shoots, branches, and cambium on a 6-point scale, with subsequent estimation of the total score of variety freezing [12]. The overall condition of the trees was 
assessed in early autumn on a five-point scale, taking into account the thickness of the stem, overall growth, strength of shoots growth, intensity of leaf color, and presence of mechanical damage [12]. The analysis of fruiting was carried out on the basis of tree yield data for the period from 2008 to 2020 . The weight accounting of the crop was carried out on all trees of each variety, followed by the calculation of the average productivity of the tree and the calculation of the yield per 1 ha [12]. Statistical data processing was carried out by the dispersion analysis method according to Dospekhov [13].

\section{Research results}

Since the beginning of the experiment, the most unfavorable periods for black cherries overwintering were the winter periods of 2005/2006 and 2011/2012, as well as the spring of 2020. The winter of $2005 / 2006$, according to the classification of Shashko D.I [14], was cold, such winters in the Astrakhan region, according to meteorologists, occur once in 4050 years. The air temperature in the second and third decades of January decreased to $31.1^{0}$, and on the surface of the soil in the complete absence of snow cover - to $-36{ }^{0} \mathrm{C}$. In young trees, damage to the bark, wood of branches and annual shoots was noted, all flower buds were frozen out. In the 4th year, all varieties formed generative buds and had to bloom, which indicates the rapidity of the studied varieties when grown in arid conditions.

The total degree of freezing was 2.5 points, the recovery processes were rather weak and did not exceed 2.2 points. Experiment trees of all varieties bloomed and gave their first fruits only in the 6th year after planting.

Studies have shown that in the next three years, the productivity of trees increased, and the yield of varieties was 4.0-24.5 kg/tree or 1.7-10.2 t/ha. In the initial period of fruiting, the productivity potential was realized to a greater extent by the varieties Aprelka, Krasavitsa and Mlievskaya Chernaya $(18.5-24.5 \mathrm{~kg} /$ tree or $7.7-10.2 \mathrm{t} / \mathrm{ha}$ ), which are $2-5$ times higher than the productivity of the varieties Salgirnaya, Negrityanka and Galochka (4.0-10.0 kg/tree or 1.7-4.2 t/ha). In the Krasavitsa variety, there were no statistically proven differences in yield with the control, although it is $3.3 \mathrm{~kg} /$ tree. or $1.4 \mathrm{t} / \mathrm{ha}$ exceeded the April crop yield (Table 1).

Table 1. Yield of black cherry varieties in the initial period of fruiting (7-9 years of growth in the garden)

\begin{tabular}{|l|c|c|c|c|c|}
\hline \multirow{2}{*}{ Variety } & \multicolumn{2}{|c|}{$\begin{array}{c}\text { Productivity, } \\
\mathrm{kg} / \text { tree }\end{array}$} & \multicolumn{2}{c|}{$\begin{array}{c}\text { Yield, } \\
\text { t/ha }\end{array}$} & \multirow{2}{*}{$\begin{array}{c}\text { Fruit } \\
\text { weight, } g\end{array}$} \\
\cline { 2 - 5 } & 2009 & 2011 & 2009 & 2011 & \\
\hline Aprelka & 1.8 & 21.2 & 0.7 & 8.8 & 3.8 \\
\hline Salgirnaya & 0.5 & 8.3 & 0.2 & 3.5 & 4.3 \\
\hline Negrityanka & 2.3 & 10.0 & 0.9 & 4.2 & 5.0 \\
\hline Galochka & 0.9 & 4.0 & 0.4 & 1.7 & 5.4 \\
\hline Krasavitsa & 0.6 & 24.5 & 0.2 & 10.2 & 5.6 \\
\hline $\begin{array}{l}\text { Mlievskaya } \\
\text { chernaya }\end{array}$ & 10.3 & 18.5 & 4.3 & 7.7 & 6.1 \\
\hline LSD $_{05}$ & & 7.0 & & 3.0 & \\
\hline
\end{tabular}

In the moderately cold winter of 2011/2012, with a sharp transition from heat to cold in January and a subsequent decrease in air temperature in February to critical values ($34.8^{\circ} \mathrm{C}$ ), there was a freezing of trees and a significant death of flower buds, all varieties sharply reduced yield. The maximum yield reduction occurred in the control variety Aprelka $-65 \%$, the minimum in the variety Salgirnaya - 39\%, in the other varieties $-45 \%$. At the same time, the varieties Aprelka, Krasavitsa and Mlievskaya Chernaya, as in the 
initial period of fruiting, significantly exceeded the productivity of the other varieties (7.511.1 and $1.8-5.1 \mathrm{~kg} /$ tree, respectively).

In the next 5 years (11-15 years of growth in the garden), temperature changes in winter were observed almost annually, but no significant freezing of flower buds was recorded. During this period, the maximum productivity of trees was noted in the varieties Aprelka and Krasavitsa (15.4 and $17.3 \mathrm{~kg} /$ tree or $6.4-7.2 \mathrm{t} / \mathrm{ha}$ ). Since 2017 , the differences in yield of Salgirnaya and Negrityanka varieties smoothed, and as wwell as a Mlievskaya Chernaya variety they were characterized by good fruiting $(9.0-11.0 \mathrm{~kg} /$ tree or $3.7-4.6 \mathrm{t} / \mathrm{ha})$. The most unproductive variety was the Galochka variety, which fruit yield from the tree did not exceed $4.5 \mathrm{~kg}(1.9 \mathrm{t} / \mathrm{ha})$.

Since the 16th year of operation (10-11 years of fruiting), the productivity of varieties has decreased. The decrease in productivity compared to the previous five years was 23.9$55.4 \%$. Probably, this is due to the influence of extremely high temperatures $\left(39.6-40.5^{\circ} \mathrm{C}\right)$, low precipitation $(38.5-56.6 \mathrm{~mm})$ in the summer periods of 2017 and 2018, which negatively affected the differentiation of flower buds and, accordingly, the yield of subsequent years. It is possible that the varieties reached the peak of fruiting, and the productivity of the trees began to decline. This will be established in the course of further observations.

In 2020, the largest yield loss for the entire accounting period was recorded from the return frosts observed during the separation of buds in the first decade of April $\left(-6.7^{0} \mathrm{C}\right)$. The varieties Aprelka (control), Mlievskaya Chernaya and Krasavitsa, which in previous years were characterized by high productivity, were hit particularly hard. Efficiency of Apelika and Mlievskaya Chernaya decreased to $0.7-0.6 \mathrm{~kg} /$ tree, and the Krasavitsa variety yield was lost completely. The Galochka variety, on the contrary, turned out to be the most resistant to return frosts, and for the first time the productivity of trees reached the maximum values $(9.6 \mathrm{~kg} / \mathrm{tree})$ and exceeded the indicators of all other varieties. Apparently, this is due to the fact that over the past 10 years, the winter period of 2019/2020 was the mildest, with a minimum air temperature of $7.6{ }^{\circ} \mathrm{C}$ below the long-term average. In the conditions of a mild winter, unlike in previous years, the flower buds of the Galochka variety did not freeze, and for the first time it fully realized its productivity potential.

The total productivity for the last 5 years of commercial fruiting, depending on the variety, was $28.5-69.4 \mathrm{~kg} /$ tree. In terms of total $(66.1-69.4 \mathrm{~kg} /$ tree) and average productivity $(13.2-13.9 \mathrm{~kg} /$ tree or $5.5-5.8 \mathrm{t} / \mathrm{ha})$, as in previous years, the Aprelka and Krasavitsa varieties stood out, despite the absence of a yield in 2020. Negrityanka, Salgirnaya and Mleevskaya Chernaya varieties also had sufficiently high average productivity (10.2-11.7 $\mathrm{kg} /$ tree) or $4.2-4.9 \mathrm{t} / \mathrm{ha})$. Reliably significant differences in productivity and yield in comparison with the control were revealed only in the Galochka variety (table 2).

Table 2. Viability and yield of black cherry varieties for the 13th-18th years of growth in the garden

\begin{tabular}{|c|c|c|c|c|c|c|}
\hline \multirow{3}{*}{ Variety } & \multirow{3}{*}{$\begin{array}{c}\text { Trees } \\
\text { viability, } \\
\%\end{array}$} & \multirow{3}{*}{$\begin{array}{c}\text { General } \\
\text { conditio } \\
\mathrm{n} \text { of the } \\
\text { trees, } \\
\text { point }\end{array}$} & \multirow{2}{*}{\multicolumn{2}{|c|}{$\begin{array}{c}\text { Productivity, kg/tree } \\
2016-2020\end{array}$}} & \multirow{3}{*}{$\begin{array}{c}\text { Yield, t/ha } \\
2016-2020 \\
\text { average }\end{array}$} & \multirow{3}{*}{$\begin{array}{c}\begin{array}{c}\text { Productivity, } \\
\mathrm{kg} / \text { tree }\end{array} \\
2020\end{array}$} \\
\hline & & & & & & \\
\hline & & & total & average & & \\
\hline Aprelka & 100 & 4.5 & 66.1 & 13.2 & 5.5 & 0.7 \\
\hline Salgirnaya & 93.7 & 3.5 & 51.1 & 10.2 & 4.2 & 3.2 \\
\hline Negrityanka & 93.7 & 3.8 & 54.9 & 11.0 & 4.6 & 5.4 \\
\hline Galochka & 100 & 4.0 & 28.5 & 5.7 & 2.4 & 9.6 \\
\hline Krasavitsa & 100 & 4.0 & 69.4 & 13.9 & 5.8 & - \\
\hline
\end{tabular}




\begin{tabular}{|l|c|c|c|c|c|c|}
\hline $\begin{array}{l}\text { Mlievskaya } \\
\text { chernaya }\end{array}$ & 100 & 4.2 & 58.7 & 11.7 & 4.9 & 0.6 \\
\hline LSD $_{05}$ & & & & 3.0 & 1.3 & 2.8 \\
\hline
\end{tabular}

Accountings conducted in the fall of 2020 showed that in the 18th year of plantings operation, $6.3 \%$ of tree fallouts are only in the Salgirnaya and Negrityanka varieties. A fairly good condition of the trees was noted in the Aprelka variety (4.5 points), slightly worse in the Galochka, Krasavitsa and Mlievskaya Chernaya varieties (4.0-4.2 points). The trees varieties Salgirnaya and Negrityanka look more depleted (3.5-3.8). Observations of the varieties continue; it is necessary to assess the duration of the productive period and the durability of the plantings.

Currently, the North Caucasus Federal Research Center for Horticulture, Viticulture, and Winemaking has attracted 13 large-fruited black cherry varieties from recent years of breeding to select a modern adaptive assortment for arid conditions.

\section{Conclusions}

As a result of a long-term study of the productivity of black cherry varieties, it was found that the studied varieties were characterized by early maturity, regular fruiting, and high preservation of trees during 18 years of plantings operation. The most productive varieties during the entire fruiting period were Aprelka (control) and Krasavitsa, which have sufficient generative buds resistance to low temperatures and its changes in winter. Despite the small fruit size (the average weight of the fruit is $3.8 \mathrm{~g}$ ), Aprelka is in great demand among the population due to regular fruiting and the earliest maturation. It is with this variety that the black cherry season begins. The Krasavitsa variety in terms of fruit size (5.6 g) corresponds to the zoned varieties. Negrityanka, Salgirnaya and Mlievskaya Chernaya varieties have the average productivity. The Galochka variety is characterized by a high generative buds resistance to return frosts and is of interest for breeding on this basis. The obtained data indicate the possibility of successful cultivation of black cherries in the specific climatic conditions of the Astrakhan region using varieties with increased winter hardiness.

\section{References}

1. A.V. Solonkin, O.A. Nikolskaya, E.N. Kikteva, G.V. Kasyanova, Scientific and Agronomic Journal, 20 (2019)

2. L.G. Demenina, Stone fruit crops in Samara Research Institute "Zhigulevskiye sady", Modern trends in the development of industrial horticulture, collection of works of the All-Russian Scientific and Practical Conference dedicated to the 125th anniversary of the birth of the scientist, breeder of stone fruit cultures, 20 (2012)

3. Analytical review of world trade on the market, https://www.indexbox.ru/

4. Analysis of the cherry and black cherry market in Russia in 2015-2019, https://marketing.rbc.ru/

5. Commercial cultivation of black cherries, ASPRUS, http://asprus.ru/

6. G.Yu. Upadysheva, Fruit and Berry growing in Russia: collection of scientific papers, XLIX, 341 (2017)

7. E.M. Alyokhina, Kubansad, 17(5), 8 (2012)

8. R. Mittler, Trends Plant Sci., 11, 15 (2006)

9. J.H. Zhang, W.D. Huang, Y.P. Liu, J Integr Plant Biol., 47, 959 (2005) 
10. P. Volienweider, M.S. Gunthardt-Goerg, Environ Pollut., 137, 455 (2005)

11. A.N. Minin, E.Kh. Nechaeva, N.A. Melnikova, V.M. Tsarevskaya, Chief Agronomist, 6 (2020)

12. Program and methodology of variety study of fruit, berry and nut crops, All-Russian Research Institute of Fruit Crops Breeding, 606 (1999)

13. B.A. Dospekhov, Methodology of field experience, 351(1985)

14. D.I. Shashko, Agroclimatic zoning of the USSR, 100 (Kolos Publishing House, 1967) 